$4-1-2008$

\title{
The state of the art in evaluating the performance of assistant and associate deans as seen by deans and assistant and associate deans.
}

\author{
David G. Dunning \\ University of Nebraska Medical Center, ddunning@unmc.edu \\ Timothy M. Durham \\ University of Nebraska Medical Center \\ Mert N. Aksu \\ University of Nebraska Medical Center \\ Brian M. Lange \\ University of Nebraska Medical Center, blange@unmc.edu
}

Tell us how you used this information in this short survey.

Follow this and additional works at: https://digitalcommons.unmc.edu/cod_articles

Part of the Dentistry Commons

\section{Recommended Citation}

Dunning, David G.; Durham, Timothy M.; Aksu, Mert N.; and Lange, Brian M., "The state of the art in evaluating the performance of assistant and associate deans as seen by deans and assistant and associate deans." (2008). Journal Articles: College of Dentistry. 3.

https://digitalcommons.unmc.edu/cod_articles/3

This Article is brought to you for free and open access by the College of Dentistry at DigitalCommons@UNMC. It has been accepted for inclusion in Journal Articles: College of Dentistry by an authorized administrator of DigitalCommons@UNMC.For more information, please contact digitalcommons@unmc.edu. 


\title{
The State of the Art in Evaluating the Performance of Assistant and Associate Deans as Seen by Deans and Assistant and Associate Deans
}

\author{
David G. Dunning, Ph.D.; Timothy M. Durham, D.D.S., M.P.A.; Mert N. Aksu, D.D.S.,
} J.D., M.H.S.A.; Brian M. Lange, Ph.D.

Abstract: This study explores the little-understood process of evaluating the performance of assistant and associate deans at dental colleges in the United States and Canada. Specifically, this research aimed to identify the methods, processes, and outcomes related to the performance appraisals of assistant/associate deans. Both deans and assistant/associate deans were surveyed. Forty-four of sixty-six deans (66.7 percent) and 227 of 315 assistant/associate deans (72.1 percent) completed surveys with both close-ended and open-ended questions. In addition, ten individuals from each group were interviewed. Results indicate that 75-89 percent of assistant/associate deans are formally evaluated, although as many as 27 percent may lack formal job descriptions. Some recommended best practices for performance appraisal are being used in a majority of colleges. Examples of these best practices are having at least yearly appraisals, holding face-to-face meetings, and setting specific, personal performance objectives/benchmarks for assistant/associate deans. Still, there is much room to improve appraisals by incorporating other recommended practices. Relatively high levels of overall satisfaction were reported by both assistant/associate deans and deans for the process and outcomes of appraisals. Assistant/associate deans rated the value of appraisals to overall development lower than did deans. Qualitative data revealed definite opinions about what constitutes effective and ineffective appraisals, including the use of goal-setting, timeliness, and necessary commitment. Several critical issues related to the results are discussed: differences in perspectives on performance reviews, the importance of informal feedback and job descriptions, the influence of an assistant/associate deans' lack of tenure, and the length of service of deans. Lastly, recommendations for enhancing performance evaluations are offered.

Dr. Dunning is Professor, Department of Oral Biology, College of Dentistry, University of Nebraska Medical Center; Dr. Durham is Professor and Chair, Department of Hospital Dentistry, College of Dentistry, University of Nebraska Medical Center; Dr. Aksu is Associate Dean, Clinical Administration, and Associate Professor, Department of Patient Management, School of Dentistry, University of Detroit-Mercy; and Dr. Lange is Professor, Department of Oral Biology, College of Dentistry, University of Nebraska Medical Center. Direct correspondence and requests for reprints to Dr. David Dunning, Department of Oral Biology, College of Dentistry, University of Nebraska Medical Center, 40th and Holdrege Sts., Lincoln, NE 68583-0740; 402-472-1325 phone; 402-472-2551 fax; ddunning@unmc.edu.

This research was conducted under a project, "The State of the Art in Evaluating the Performance of Department Chairpersons and Assistant/Associate Deans in ADEA-Affiliated Dental Colleges," conducted July 2004-June 2007, and funded by the American Dental Education Association's Council of Sections Project Pool with additional support from the Section on Practice Administration and the Section on Graduate and Postgraduate Education.

Key words: performance review, performance appraisal, performance evaluation, assistant deans, associate deans, dental colleges

Submitted for publication 8/29/07; accepted 12/14/07

\begin{abstract}
A previous study published by the authors of this article provided a detailed literature review pertaining to the evaluation processes of administrators in dental colleges. ${ }^{1}$ Relatively few publications have addressed the performance evaluation of administrators in academic health sciences centers. ${ }^{2-21}$ Some highlights of previous research include the following:
\end{abstract}

1) the identification of factors used in evaluating department chairs, ${ }^{3}$ as well as administrator and faculty opinions of the appraisals, particularly of faculty members and departments; ${ }^{4-8}$

2) efforts to link faculty teaching and department reviews to organizational missions and budgets; $;, 10$

3) an assessment of department chair appraisals in community colleges; ${ }^{11}$

Journal of Dental Education - Volume 72, Number 4 
4) a three-volume set by Biebuyck and Mallon focusing on performance, evaluation, rewards, and renewal of department chairs and delineating key appraisal features and sources of feedback; $;^{12-14}$

5) two studies describing evaluation instruments for faculty and administrators, ${ }^{15,16}$ including an evaluation form and recommendations for assessing dental administrators delineated by Romberg et al.;16

6) three articles describing the role of administrators in evaluating faculty; ${ }^{17-19}$ and

7) two articles about evaluating nursing school deans. ${ }^{20,21}$

The extant literature thus indicated a clear need for more research regarding the evaluation of administrators generally and, specifically in this case, assistant and associate deans in dental schools. To address this knowledge gap, the goal of this research was to examine the current practices, processes, and outcomes related to evaluating the job performance of assistant and associate deans in American Dental Education Association (ADEA)-affiliated dental schools.

\section{Methods}

\section{Materials}

Approval for the project was secured through the first author's institutional review board (IRB \#038-04-EX). The first phase of the project involved the evaluation of department chairs. ${ }^{1}$ Electronic survey administration for the department chair study occurred from February through April 2005, and phone interviews followed. For this second study focusing on the evaluation of assistant/associate deans, draft surveys were developed and mailed to five deans and five assistant/associate deans for pilot-testing in March 2006. Three deans and four assistant/associate deans returned the draft surveys with helpful recommendations for improvement.

Based on our earlier study of department chairs, several specific survey refinements were incorporated into the survey on assistant/associate dean evaluations. First, a question was added asking about the relative importance of research to the institution (research-intensive, research a priority but not research-intensive, and teaching the primary emphasis/priority). Second, in the earlier study of department chairs, one question asked whether feedback from at least one source other than the dean was assimilated into the appraisal process. In this study, a specific question asked about each unique source of performance feedback for assistant/associate deans: students, staff, faculty, department chairs/ division heads, and other administrators (such as peers). Third, an item was added regarding satisfaction with the overall evaluation process (formal and informal). Fourth, a question was modified: instead of asking about the value of appraisals to personal development, the survey item queried the value of appraisals to overall development. Fifth, to facilitate the recruiting of potential interviewees, respondents were asked about their willingness to be interviewed at a later time regarding performance evaluations of assistant/associate deans.

The final surveys thus included twenty-seven questions for deans and twenty-nine questions for assistant/associate deans, the additional questions for the latter pertaining to academic rank and tenure. Deans were not queried about academic rank or tenure. Questions covered these areas: type of dental school (public vs. nonpublic), length of service, job descriptions, relative importance of research to the institution, features utilized in performance evaluations, frequency of and length of time since the last performance appraisal, satisfaction with the process and outcomes of evaluations using a five-point scale ( $1=$ very dissatisfied to $5=$ very satisfied), rankings of the purposes for evaluations, ratings of the value of appraisals ( $1=$ no value to $5=$ very valuable), openended comments regarding appraisals, receipt of informal feedback, the frequency of and satisfaction regarding informal feedback (based on the same five-point scale), and an open-ended question for summarizing a particularly successful/unsuccessful story regarding performance appraisals.

\section{Respondents}

ADEA's 2005-06 directory ${ }^{22}$ provided email addresses for dental school deans and assistant/ associate deans. Based on this source, sixty-six dental deans and 315 assistant/associate deans were serving at the beginning of this study. Some turnover ensued during the administration of the survey: for example, two or three interim deans assumed dean positions. An initial email invitation (utilizing www. surveymonkey.com and including a link to decline participation) was sent in June 2006 to the sixty-six deans/interim deans and 315 assistant/associate deans. The electronic survey program incorporated helpful "logic" whereby participants were automati- 
cally directed to certain questions based on their answers. Participants were linked by double-clicking to the survey at surveymonkey.com's website. Three follow-up emails were sent from June to August 2006 only to nonrespondents who had not declined to participate. All of the emails included the first author's name in the "From" line. Respondents were also invited at the end of the survey to send copies of performance appraisal forms to the authors of this article. Forty-four of sixty-six deans (66.7 percent) and 227 of 315 assistant/associate deans (72.1 percent) completed surveys.

Quantitative data from the surveys were then exported/imported into SAS for analysis. The following statistics were computed: descriptive (means and percentages), comparisons of means using ANOVA, and comparisons of proportional data using chisquare analysis. While the entire population of deans and assistant/associate deans was surveyed, the data obtained are nevertheless a sample of that population; hence, the use of ANOVA and chi-square analysis tests are still appropriate. Responses to the three written survey questions were extracted verbatim from the data set and content-analyzed by one member of the research team in order to identify qualitative categories or themes. Three deans and forty-eight assistant/associate deans listed reasons that performance reviews were not done. Ten deans and fortytwo assistant/associate deans provided comments related to the frequency, process, outcome, or purpose of performance appraisals. Eleven deans and seventytwo assistant/associate deans wrote brief accounts of particularly successful/unsuccessful experiences in the performance evaluation process.

To augment the survey data, two research team members conducted follow-up telephone interviews ranging from seven to thirty minutes with a sample of ten deans and ten assistant/associate deans. The interviewees were selected in a stratified manner to mirror the percentages of survey participation. Fourteen individuals (seven from each group) who had volunteered to be interviewed in the survey were selected at random from within the larger group of volunteers. The other six interviewees (three from each group who had not completed the survey) were recruited to participate via phone or email. These individuals also were selected at random from among nonrespondents.

The eight interview questions covered these topics: key elements of and obstacles to making formal appraisals effective or valuable, an example of an effective or ineffective appraisal, advice for those involved in the performance evaluation process, key elements of and obstacles to making informal feedback effective or valuable, and advice for those who provide informal feedback. These recorded interviews were then content-analyzed by two research team members. Content-analysis involved the development of common themes/points emerging from the comments provided by interviewees. The unit of analysis was a statement made by participants in answering each of the interview questions. Common themes/points thus were built upon at least three or more interviewees' making essentially the same statement in response to a question.

\section{Results}

\section{Quantitative Survey Findings}

Overall Results for Deans and Assistant/ Associate Deans. Table 1 reports the characteristics of respondents. Percentages have been rounded up and down to the next whole number in all the tables; thus, totals may not equal 100 percent. As could be expected, most respondents were from public schools (71 percent and 68 percent). Fifty-percent of deans and 47 percent of assistant/associate deans reported working in "research-intensive" colleges, with only 11 percent at institutions with teaching as the primary priority. Seventy-three percent of deans and 68 percent of assistant/associate deans had four or more years' experience in their positions. While nearly 84 percent of deans reported that assistant/associate deans in their colleges had job descriptions, fewer assistant/associate deans ( 73 percent) reported having job descriptions for their positions. No significant differences were observed in comparing the two groups and the variables in Table 1.

Table 2 lists information on the formal evaluations. The vast majority of both deans and assistant/ associate deans reported that formal evaluations were conducted ( 89 percent and 75 percent, respectively) once a year (90 percent and 93 percent). Ninety-percent of deans and 87 percent of assistant/associate deans reported the time since the last evaluation as twelve months or less. Deans were neutral about (3.00) and assistant/associate deans somewhat in favor (3.66) of providing formal evaluations for those not being so evaluated. No significant differences were seen in comparing deans and associate deans on the variables listed in Table 2 .

Table 3 presents features of the appraisal process and sources from which performance feedback is 


\begin{tabular}{|c|c|c|}
\hline 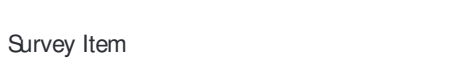 & $\begin{array}{l}\text { Deans } \square \\
(\mathrm{n}=44) \square\end{array}$ & $\begin{array}{c}\text { Assistant and Associate Deans } \square \\
\qquad(\mathrm{n}=227) \square\end{array}$ \\
\hline \multicolumn{3}{|l|}{ Type of School/College } \\
\hline Private $\square$ & $23 \% \square$ & $24 \%$ \\
\hline Private state-related (some public funding) $\square$ & $7 \% \square$ & $7 \%$ \\
\hline Public $\square$ & $71 \% \square$ & $68 \% \square$ \\
\hline \multicolumn{3}{|c|}{ Describe the relative role of research in your dental college. } \\
\hline Very strong priority (research-intensive) & $50 \% \square$ & $47 \%$ \\
\hline A priority but not research-intensive $\square$ & $39 \% \square$ & $42 \%$ \\
\hline Teachingis the primary priority $\square$ & $11 \% \square$ & $12 \%$ \\
\hline \multicolumn{3}{|l|}{ Length of Service of Dean } \\
\hline 3years or tess $\square$ & $27 \% \square$ & $32 \%$ \\
\hline 4-9 years $\square$ & $50 \% \square$ & $45 \%$ \\
\hline 10 yearsormore $\square$ & $23 \% \square$ & $23 \%$ \\
\hline \multicolumn{3}{|l|}{ Job Descriptions for Assistant/Associate Deans } \\
\hline Yes $\square$ & $84 \% \square$ & $73 \%$ \\
\hline No $\square$ & $16 \% \square$ & $20 \%$ \\
\hline Unsure $\square$ & $0 \% \square$ & $7 \%$ \\
\hline \multicolumn{3}{|c|}{ Note: Percentages have been rounded, so totals may not equal $100 \%$. } \\
\hline \multicolumn{3}{|c|}{ Table 2. Information about formal evaluations, by percentage of total respondents } \\
\hline Survey Item $\square$ & Deans $\square$ & Assistant and Associate Deans $\square$ \\
\hline \multicolumn{3}{|l|}{ Formally evaluated? } \\
\hline Yes $\square$ & $89 \% \square$ & $75 \%$ \\
\hline No $\square$ & $11 \% \square$ & $22 \% \square$ \\
\hline Unsure $\square$ & $0 \% \square$ & $4 \% \square$ \\
\hline \multicolumn{3}{|c|}{ If not formally evaluated, would the assistant/associate dean prefer to be so evaluated? } \\
\hline \multirow{2}{*}{\multicolumn{3}{|c|}{ Frequency of Appraisal }} \\
\hline & & \\
\hline$<1$ ayear $\square$ & $5 \% \square$ & $5 \%$ \\
\hline 1 ayear $\square$ & $90 \% \square$ & $93 \%$ \\
\hline 2 ayear $\square$ & $0 \% \square$ & $1 \%$ \\
\hline$>2$ a year & $5 \% \square$ & $1 \% \square$ \\
\hline \multicolumn{3}{|l|}{ Time Since Last Evaluation } \\
\hline$<6$ months $\square$ & $51 \% \square$ & $48 \%$ \\
\hline $6-12$ months $\square$ & $38 \% \square$ & $39 \%$ \\
\hline $1-2$ years $\square$ & $10 \% \square$ & $11 \%$ \\
\hline$>2$ years $\square$ & $0 \% \square$ & $2 \%$ \\
\hline \multicolumn{3}{|c|}{ Note:Percentages have been rounded, so total s may not equal $100 \%$. } \\
\hline
\end{tabular}

obtained, most of which were identified by Biebuyck and Mallon as recommendations for appraising department chairs. ${ }^{14}$ Significant differences are noted in the right-hand column. Respondents indicated a wide range of utilization of these features: from a low of 13 percent of assistant/associate deans reporting that resources are allocated based on administrative achievement of performance objectives, to a high of 92 percent of deans reporting the use of a faceto-face meeting for appraisals. Chi-square analyses showed significant differences in three of the seven performance review features. Marked differences of 17 percent, 22 percent, and 18 percent between deans and assistant/associate deans, respectively, were noted regarding the use of structured/closeended questions, the use of unstructured/open-ended questions, and the allocation of resources based on administrative achievement of performance objectives. Significant differences emerged for four of the five from which performance feedback is obtained 
for assistant/associate deans: students, staff, department chairs/heads, and peer administrators. Dean and assistant/associate dean percentages for the later two feedback sources/groups varied 20 percent and 17 percent, respectively.

Table 4 lists rankings of appraisal purposes and levels of satisfaction with evaluations. Significant differences are noted in the right-hand column. Deans ranked the top three purposes as the following: 1) personal development of assistant/associate dean (which we intended to focus respondents on individual growth and career satisfaction as contrasted with professional development); 2) assessment of job performance of assistant/associate dean in that role; and 3) assessment of administrative performance in specific areas. Assistant/associate deans ranked these same purposes as the top three, but in different order: 1) assessment of job performance of assistant/associate dean in that role; 2) assessment of administrative performance in specific areas; and 3) personal development. Two purposes were ranked significantly different: personal development of assistant/associate dean (1.97 vs. 2.84; ANOVA $\mathrm{p}=.002$ ) and compliance with university policy/procedure (4.17 vs. 3.58 ; ANOVA $p=.02$ ).

\begin{tabular}{|c|c|c|c|}
\hline Survey Item $\square$ & Deans $\square$ & $\begin{array}{c}\text { Assistant and } \square \\
\text { Associate Deans } \square\end{array}$ & Chi-square/p value $\square$ \\
\hline \multicolumn{4}{|l|}{ Features of Evaluation Process } \\
\hline Using structured/close-ended questions $\square$ & $36 \% \square$ & $53 \% \square$ & .05 \\
\hline Using unstructured/open-ended questions $\square$ & $62 \% \square$ & $40 \% \square$ & .02 \\
\hline Setting of speci $\subset$, personal performance objectives/benchmarks $\square$ & $56 \% \square$ & $63 \% \square$ & \\
\hline $\begin{array}{l}\text { Setting administrative performance objectives on basis of college } \square \\
\text { or university strategic plan/goals } \square\end{array}$ & $\begin{array}{c}62 \% \square \\
\square\end{array}$ & $\begin{array}{c}50 \% \square \\
\square\end{array}$ & $\square$ \\
\hline $\begin{array}{l}\text { Allocating resourcesbased on administrative achievement of } \square \\
\text { performance objectives } \square\end{array}$ & $\begin{array}{c}31 \% \square \\
\square\end{array}$ & $\begin{array}{c}13 \% \square \\
\square\end{array}$ & $.007 \square$ \\
\hline Meeting face-to-face to review $\square$ & $92 \% \square$ & $88 \% \square$ & \\
\hline Assistant/associate dean self-evaluation/appraisal $\square$ & $51 \% \square$ & $44 \% \square$ & \\
\hline \multicolumn{4}{|c|}{ Additional sources from which feedback is requested and assimilated in formal appraisal } \\
\hline Students $\square$ & $33 \% \square$ & $19 \% \square$ & .03 \\
\hline Staff $\square$ & $28 \% \square$ & $14 \% \square$ & .05 \\
\hline Faculty $\square$ & $36 \% \square$ & $23 \% \square$ & \\
\hline Department chairs/heads $\square$ & $59 \% \square$ & $39 \% \square$ & .02 \\
\hline Peer administrators $\square$ & $46 \% \square$ & $29 \% \square$ & .04 \\
\hline
\end{tabular}

Table 4. Ranked purposes and levels of satisfaction

\begin{tabular}{|c|c|c|c|}
\hline Survey Item $\square$ & $\begin{array}{c}\text { Deans } \square \\
\square\end{array}$ & $\begin{array}{c}\text { Assistant and } \square \\
\text { Associate Deans } \square\end{array}$ & ANOVA/p value $\square$ \\
\hline $\begin{array}{l}\text { Ranked Purposes of Appraisals } \\
\text { (1 to } 5 \text { with } 1 \text { the mostlimportant purpose) }\end{array}$ & $\square$ & & \\
\hline Personal development of assistant/associate dean $\square$ & $1.97 \square$ & $2.84 \square$ & .002 \\
\hline Justi $\lceil$ cation for salary adjustment $\square$ & $3.64 \square$ & 3.52 & \\
\hline Assessment of job performance of assi stant/associate dean in that role $\square$ & $2.17 \square$ & 2.00 & \\
\hline Assessment of administrative performancein speci c areas $\square$ & $2.65 \square$ & 2.51 & \\
\hline Compliance with university policy/procedure $\square$ & $4.17 \square$ & 3.58 & \\
\hline Other purpose not Iisted above & $4.00 \square$ & $3.86 \square$ & .02 \\
\hline $\begin{array}{l}\text { Overall Satisfaction with Process } \\
\text { (1 to } 5 \text { scal ewith } 5 \text { being very satis } \square \text { ed) }\end{array}$ & $3.79 \square$ & $4.02 \square$ & $\square$ \\
\hline $\begin{array}{l}\text { Overall Satisfaction with Outcomes } \\
\text { (1 to } 5 \text { scal ewith } 5 \text { being very satis ed) }\end{array}$ & $3.97 \square$ & $4.09 \square$ & $\square$ \\
\hline $\begin{array}{l}\text { Value of Appraisals to Assistant/Associate Dean's Overall Development } \\
\text { (1 to } 5 \text { scal ewith } 5 \text { being very valuable) }\end{array}$ & $3.85 \square$ & $3.36 \square$ & .006 \\
\hline
\end{tabular}


Table 5. Informal feedback and levels of satisfaction with informal feedback and with overall evaluation process, by percentage of total respondents

\begin{tabular}{|c|c|c|c|}
\hline$\square$ Survey Item $\square$ & $\begin{array}{c}\text { Deans } \square \\
\square\end{array}$ & $\begin{array}{c}\text { Assistant and } \square \\
\text { Associate Deans } \square\end{array}$ & Statistic/p value \\
\hline $\begin{array}{l}\text { Informal Feedback Provided? } \\
\text { Yes } \square \\
\text { No } \square\end{array}$ & $\begin{array}{r}100 \% \square \\
0 \% \square\end{array}$ & $\begin{array}{l}83 \% \square \\
17 \% \square\end{array}$ & Chi-square $=.003$ \\
\hline $\begin{array}{l}\text { Frequency of Informal Feedback } \\
2-3 \text { timesa week or more often } \square \\
\text { Oncea week } \square \\
2-3 \text { timesa month } \square \\
\text { Oncea month } \square \\
\text { Less than Once a month } \square \\
\text { Really only when necessary (a concern or something praiseworthy) }\end{array}$ & $\begin{array}{c}9 \% \square \\
16 \% \square \\
14 \% \square \\
19 \% \square \\
9 \% \square \\
33 \% \square\end{array}$ & $\begin{array}{r}10 \% \square \\
8 \% \square \\
13 \% \square \\
19 \% \square \\
9 \% \square \\
42 \% \square\end{array}$ & \\
\hline $\begin{array}{l}\text { Satisfaction with Informal Performance Feedback } \\
\text { (1 to } 5 \text { scalewith } 5 \text { being very satis ed) }\end{array}$ & $4.14 \square$ & 3.95 & \\
\hline $\begin{array}{l}\text { Satisfaction with Overall Evaluation Process, Formal and Informal, } \\
\text { for Assistant/Associate Deans }\end{array}$ & 4.05 & $3.65 \square$ & ANOVA $=.02$ \\
\hline Note: Percentages have been rounded, so total s may not equal $100 \%$ & & & \\
\hline
\end{tabular}

Both groups rated satisfaction with the appraisal process and with evaluation outcomes at fairly high levels (3.79 to 4.09 on a scale of 1 to 5 with 5 being very satisfied). Deans rated the importance of appraisal to assistant/associate dean's overall development more highly than did their counterparts (3.85 vs. 3.36; $\mathrm{ANOVA}=.006$ ).

Table 5 delineates results related to informal feedback and satisfaction with informal feedback as well as the overall evaluation process. Whereas all deans reported giving informal feedback to assistant/associate deans, the latter reported 83 percent, a significant difference (chi-square $\mathrm{p}=.003$ ). Clearly, the most highly reported frequency for informal feedback was "only when necessary"-namely, when a concern or something praiseworthy arises (33 percent and 42 percent for each group). Satisfaction with informal feedback was rated at 4.14 by deans and at 3.95 by assistant/associate deans. Deans reported a significantly higher level of satisfaction with the overall evaluation processes (formal and informal): 4.05 vs. 3.65 $(\mathrm{ANOVA}=.02)$

Table 6 summarizes characteristics of assistant/associate deans. Fifty-five percent of assistant/associate deans reported being tenured, with 47 percent and 31 percent being either full or associate professors. Fifteen percent had an academic rank of "other." Sixty-six percent had four or more years of experience. Most assistant/associate deans (53 percent) do not have the opportunity to provide formal feedback to their deans/supervising administrators, and 45 percent of these would like this opportunity.

Table 6. Characteristics of assistant/associate deans, by percentage of total respondents

Survey Item $\square$

\begin{tabular}{lc}
\hline Tenured & \\
Yes $\square$ & $55 \%$ \\
No $\square$ & $45 \%$ \\
Academic Rank & \\
Professor $\square$ & $47 \%$ \\
Associate:Professor $\square$ & $31 \%$ \\
Assistant Professor $\square$ & $8 \%$ \\
Other (non-faculty/staff, instructor, administrator, etc.) $\square$ & $15 \%$ \\
Length of Service of Assistant/Associate Dean & \\
3 years or Iess $\square$ & $34 \%$ \\
$4-9$ years $\square$ & $40 \%$ \\
10 years or more $\square$ & $26 \%$ \\
Opportunity to provide formal performance feedback to your & \\
dean/supervising administrator? & \\
Yes $\square$ & $47 \%$ \\
No $\square$ & $53 \%$ \\
If you currently do not, would you like the opportunity to & \\
formally evaluate your dean/supervising administrator? & \\
Yes $\square$ & \\
No $\square$ & $45 \%$ \\
Unsure $\square$ & $20 \%$ \\
\end{tabular}

Note: Percentages have been rounded, so total s may not equal $100 \%$. 
Differences in Subgroups. In addition to Tables 1-6, comparisons were computed using these independent variables: type of college (public vs. private/private with some public funding [nonpublic]); relative importance of research using the three question options as groups; length of service using three groups established based on clusters of respondents (three years or less, four to nine years, and ten years or more); existence of job descriptions for assistant/associate deans (Yes, No, Unsure); and, for assistant/associate deans only, tenured vs. nontenured groups and academic rank (professor, associate professor, assistant professor, and other). Subgroup comparisons resulting in three or more differences are highlighted in Tables 7, 8, and 9.

These significant differences were observed in dean responses: deans from nonpublic schools rated satisfaction with informal performance feedback more highly than did their public dean peers $(4.38$ vs. 4.03; ANOVA $p=.04)$; and deans with one to three years of experience rated the value of appraisals to the overall development of assistant/associate deans significantly higher than did deans with four to nine years of experience (4.18 vs. 3.60; ANOVA p=.037).

A number of significant differences emerged among assistant/associate deans.

In comparing public and nonpublic colleges, assistant/associate deans in nonpublic colleges reported higher levels of informal performance feedback than their public college peers (ranging from 91 percent in nonpublic colleges to 79 percent in public; chi-square $\mathrm{p}=.03$ ). Assistant/associate deans in public colleges reported giving formal performance feedback to their deans more than for deans in nonpublic colleges (ranging from 52 percent in public to 38 percent in private colleges; chi-square $\mathrm{p}=.05$ ).

Table 7 lists observed differences based on the length of service of deans as reported by the assistant/associate deans:

- overall differences in being formally evaluated (ranging from 86 percent being evaluated by newer deans to 59 percent by deans with ten or more years in that position; chi-square $\mathrm{p}=.009$ );

- overall differences in frequency of formal evaluations (ranging from 98 percent being evaluated once a year by newer deans to 79 percent being evaluated less than once a year by deans with ten or more years of service; chi-square $p=.002$ );

- overall differences in the time since the last evaluation (ranging from 52 percent of those with newer deans having had evaluations in the past six months compared to 21 percent of those with deans having ten or more years of service; chi-square $\mathrm{p}=.001$ ); and

- overall differences in giving the dean formal performance feedback (ranging from 57 percent of those with newer deans to 31 percent of those with deans having ten or more years of experience; chi-square $\mathrm{p}=.02$ ).

Altogether, longer deanship seems to correspond to less formal evaluation of assistant/associate deans.

Among assistant/associate deans not formally evaluated, a significant difference in the preference to be evaluated was noted based on length of service: 3.94 for those with one to three years of service vs. 3.13 for those with ten years of service or more $(\mathrm{p}=.05)$.

Table 8 presents significant differences observed when comparing assistant/associate dean groups based on having job descriptions (yes, no, unsure):

- likelihood to be formally evaluated (ranging from 80 percent with job descriptions being formally evaluated to 55 percent of those without job descriptions being evaluated; chi-square $\mathrm{p}=.0001$ );

- rankings for salary justification as a purpose of evaluations (ranging from 3.65 for those with job descriptions to 2.67 for those unsure; overall three-group ANOVA $p=.03$ );

- receiving informal feedback (ranging from 87 percent with job descriptions receiving informal

Table 7. Differences among assistant/associate deans based on dean's length of service (as reported by assistant/associate deans), by percentage of total respondents

\begin{tabular}{|c|c|c|c|c|}
\hline Survey Item $\square$ & $\begin{array}{r}\square \quad \text { Dean } \\
1-3 \text { YearsorLess }\end{array}$ & $\begin{array}{l}\text { Length of S } \\
\text { 4-9Years }\end{array}$ & $\begin{array}{l}\text { rvice } \square \\
\text { 10Years or More }\end{array}$ & Chi-square/p value \\
\hline Formally Evaluated—Yes $\square$ & $86 \% \square$ & $74 \% \square$ & $59 \% \square$ & .009 \\
\hline Frequency of Formal Evaluations—Once a Year $\square$ & $98 \% \square$ & $94 \% \square$ & $79 \% \square$ & .002 \\
\hline Time SinceLast Evaluation—In Past Six Months $\square$ & $52 \% \square$ & $54 \% \square$ & $21 \% \square$ & .001 \\
\hline Give Dean Formal Performance Feedback-Yes $\square$ & $57 \% \square$ & $51 \% \square$ & $31 \% \square$ & .02 \\
\hline
\end{tabular}


feedback compared to 74 percent of those without job descriptions; chi-square $\mathrm{p}=.05$ );

- those with job descriptions having higher satisfaction with the overall formal and informal evaluation process compared to those without job descriptions (3.73 vs. 3.30; two-way ANOVA $\mathrm{p}=.02$ ); and

- giving the dean formal performance feedback (ranging from 52 percent of those with job descriptions giving this feedback to 19 percent of those unsure about job descriptions providing this feedback; chi-square $\mathrm{p}=.03$ ).

In summary, job descriptions appear related to increased formal evaluations, salary justification as a purpose of appraisals, higher satisfaction with the overall evaluation process, and giving upward performance feedback to deans.

Table 9 details significant differences based on the academic tenure (yes vs. no) of assistant/ associate deans:

- likelihood to be formally evaluated (83 percent of those without tenure compared to 68 percent of those with tenure; chi-square $\mathrm{p}=.04$; still, 15 percent of those without tenure reported not being evaluated);

- ranking of assessment of administrative performance in specific areas as a purpose of appraisals (2.72 for those without tenure vs. 2.33 for those with tenure; ANOVA $\mathrm{p}=.03$ ); and
- receiving informal feedback ( 89 percent for those without tenure and 79 percent of those with tenure; chi-square $=.05$ )

Assistant/associate deans with tenure seemingly receive less performance feedback.

Two additional significant differences resulted, based on the rank of the respondent (academic professor, associate professor, assistant professor, other):

- justification for salary adjustment as a purpose of evaluations (ANOVA $\mathrm{p}=.05$ across the four groups; ANOVA $p=.006$ in comparing only professors [3.78] to "other" [2.96], meaning that professors ranked justification for salary adjustment significantly lower); and

- assessment of administrative performance in specific areas in comparing professors (2.36) and "other" (2.92), indicating that professors ranked this purpose of appraisals significantly higher (ANOVA $\mathrm{p}=.02$ ).

\section{Qualitative Survey Findings}

Respondents provided written responses to several survey questions. The following points summarize their responses.

1) Deans not performing formal appraisals of their assistant and associate deans explained this on the basis of close working relationships and the frequency of regular discussions and meetings about their colleagues' goals. Few of

Table 8. Differences among assistant/associate deans based on job descriptions

\begin{tabular}{|c|c|c|c|c|}
\hline$\square$ Survey $\Perp t e m \square$ & $\begin{array}{r}\square \\
\text { Yes } \square\end{array}$ & $\underset{\text { bo }}{\operatorname{bb} \text { Description? }}$ & Unsure $\square$ & Statistic/p value \\
\hline Formally Evaluated-Yes & $80 \% \square$ & $55 \% \square$ & $75 \% \square$ & Chi-square/.0001 \\
\hline $\begin{array}{l}\text { Salary Justi cation as Purpose of Appraisals - Yes } \square \\
\square\end{array}$ & $\begin{array}{c}3.65 \square \\
\square\end{array}$ & $\begin{array}{c}3.10 \square \\
\square\end{array}$ & $\begin{array}{c}3.67 \square \\
\square\end{array}$ & $\begin{array}{c}\text { ANOVA } .03 \square \\
\text { (acrossall three groups) }\end{array}$ \\
\hline ReceiveInformal Feedback—Yes $\square$ & $87 \% \square$ & $74 \% \square$ & $69 \% \square$ & Chi-square/.05 \\
\hline Satisfaction with Overall Evaluation Process $\square$ & 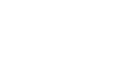 & 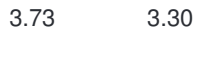 & $\begin{array}{r}\square \quad \square \\
\square\end{array}$ & $\begin{array}{l}\text { ANOVA } / .02 \\
\text { (paired comparison) }\end{array}$ \\
\hline Give Dean Formal Performance Feedback-Yes & $52 \% \square$ & $42 \% \square$ & $19 \% \square$ & Chi-square/.03 \\
\hline
\end{tabular}

Table 9. Differences among assistant/associate deans based on academic tenure

\begin{tabular}{|c|c|c|c|c|}
\hline Survey Item $\square$ & $\mathrm{Yes}^{\square \mathrm{Te}}$ & $\begin{array}{l}\text { ured? } \\
\square\end{array}$ & $\mathrm{No} \square$ & Statistic/p value \\
\hline Formally Evaluated-Yes & $68 \% \square$ & $\square$ & $83 \% \square$ & Chi-square/.04 \\
\hline $\begin{array}{l}\text { Ranking of Assessment of Administrative Performancein } \square \\
\text { Speci } \square \text { CAreas as a Purpose of Appraisals } \square\end{array}$ & $\stackrel{2.33 \square}{\square}$ & $\begin{array}{l}\square \\
\square\end{array}$ & $2.72 \square$ & ANOVA/.03 $\square$ \\
\hline ReceiveIInformal Feedback—Yes & $79 \% \square$ & $\square$ & $89 \% \square$ & Chi-square/.05 \\
\hline
\end{tabular}


these deans reported that they were conducting regular (annual) reviews of their associate and assistant deans' performance. While some deans expressed some interest in formal evaluations, most preferred an informal approach.

2) Deans reported that successful evaluation experiences were tied to keeping the assistant/associate deans focused on goals and specific elements of their job responsibilities.

3) Assistant/associate deans who did not have formal appraisals generally did not know the reason for the lack of such evaluations.

4) Assistant/associate deans offered these summarized comments on the frequency, process, outcome, or purpose of appraisals:

a. Deans should evaluate assistant/associate deans formally regularly/annually.

b. Deans should spend time with recommendations for professional growth and development of assistant/associate deans.

c. Specific characteristics of ineffective evaluations were mentioned as being evaluations conducted by deans pro forma, in a manner perceived to be subjective, and appraisals that identified problems that cannot be corrected. According to assistant/associate deans, evaluations often fall into this category.

d. 360 degree feedback and interactive evaluation processes are both valuable. We define 360 degree feedback as a process by which an individual receives input about his or her performance from all key sources impacted by that individual's work. In the case of an associate dean of research, these sources would provide performance feedback: the dean, students being mentored in research by the associate dean, peer assistant/associate deans, department chairs, staff supervised by the associate dean, and perhaps donors contributing to research efforts at the college.

5) Assistant/associate deans identified these characteristics as part of particularly effective evaluations: interaction; a dean having a solid understanding of the roles, responsibilities, and accomplishments of the assistant/associate deans; no surprises in the formal feedback; goals developed in advance; creation of an opportunity for professional development; and identification of performance strengths and weaknesses.

6) Assistant/associate deans cited these features of particularly ineffective evaluations: those done with insufficient preparation, and appraisals inadequately tailored to address the specific goals and responsibilities of the individual assistant/ associate dean.

We received fourteen evaluation forms used in appraising assistant/associate deans. Altogether, these forms varied considerably in sophistication, length, and content. Some forms included both open- and close-ended questions/items, whereas others featured only one type of question. A number of forms incorporated goal-setting or work plans for the next period of performance. Several of these forms were given to participants at ADEA Annual Session workshops on administrative performance appraisals in order to augment appraisals at their respective colleges.

\section{Interview Themes}

Responses from Deans. Deans advised utilization of these key features of the formal evaluation process:

- a self-assessment tool,

- a standardized form or evaluation matrix to guide the appraisal process,

- a goal-setting exercise by the individual in concert with the dean, integrating the school's strategic plan, and

- some form of anonymous evaluation by peers, faculty, staff, and students, centering on administrative effectiveness, leadership, and mentoring skills, as well as the universal standards of teaching, scholarship, and service.

Deans also noted that the effectiveness of the associate/assistant dean is closely linked to the dean's effectiveness. The formal evaluation process affords the dean the opportunity to congratulate these administrators on their work effort, while also tactfully redirecting administrators into better alignment with the strategic plan. The closer assistant/associate deans are to the dean relationally and strategically, the more important this alignment becomes.

Deans recognize that an efficacious formal appraisal process consumes a considerable amount of time. Ideally, evaluations probably should be done every six months rather than annually and must be reinforced and enlivened through consistent informal feedback. Incremental interactions prevent the "ahha" moments of surprise that can negatively impact the relationship. The formal evaluation process requires preparation, and most people appreciate the time invested in them and the acknowledgment of their work effort. Properly done, formal evaluations 
create trust and confidence in leadership. Ideally, a longer relationship with the dean results in more trust and more straightforward, candid, and honest information exchange. Openness in communication is at the heart of the process, evidenced by an appropriate balance of structure and formality so that creativity, synergy, and consensus-building can be maximized. Performance evaluations also ensure that outcome measures are clear, developed collectively, and benchmarked for progress. Being unprepared, just going through the motions, or inflating the evaluation are all unfair to the administration and the organization. Properly executed and integrated into the organizational culture, appraisals create strategic alignment for advancing the cause, while also providing the opportunity to guide personal/professional growth and development with positive, purposeful intention.

With respect to informal evaluations, deans again focused on the concepts of strategic alignment and fostering and building relationships. Informal feedback needs to be timely so it can be pre-emptive if necessary or positively reinforcing as needed. An important element is having the emotional intelligence to not miss the appropriate moment and to understand how the other individual likes to be approached and acknowledged regarding his or her work effort. This may require some creativity and the use of more personal notes, which add an individual specific touch. Disingenuous praise at the wrong time and place can be disastrous to the relationship and morale of others who witness it. Informal feedback must, therefore, have a definite purpose that stays on message and augments effectiveness. Informal feedback should be viewed as an integral part of the formal appraisal process and, when used correctly, can lower the intimidation of formal appraisals, generate new goals, and overcome resistance to strategic directions.

Collectively, the formal and informal appraisal processes establish clarity with respect to performance expectations. There must also be an underlying faith in human nature expressed in the belief that most people want to do the right thing. The key is to align the individual's concept of doing the right thing with the organization's concept of doing the right thing. This alignment must also embrace the ethical and moral right thing in producing constructive outcomes and achieving goals. Providing such balanced and effective leadership is, obviously, a challenge.

Responses from Assistant and Associate Deans. Assistant and associate deans indicated that effective formal appraisals should be based on clearly assigned duties, a mutual understanding of goals for each person involved in the process, and goals developed well in advance of the evaluation. Additionally, assistant and associate deans recommended that evaluations be based on 360 degree performance feedback from all sources/areas in which the individual has assigned responsibilities.

Two key obstacles in formal evaluations were identified by assistant and associate deans: a lack of effort on the part of administrators to conduct timely performance appraisals, and the fear of having to deliver a negative evaluation. Ineffective formal evaluations were characterized as having no clear expectation of what an individual should be doing and not involving the individual in a meaningful dialogue about his or her work responsibilities and priorities.

The advice that assistant and associate deans gave on how to conduct formal evaluations included calls for the following: honesty, objectivity, use of goals for the individual aimed at focusing effort on key performance areas, and consistent utilization of the appraisal process in place.

Assistant and associate deans provided several insights related to giving informal feedback. Informal feedback should center on an individual's goals or a specific task. In addition, informal feedback is best when given in a timely, candid, and honest manner. Three obstacles were identified regarding giving informal feedback: its time-consuming nature, individual egos creating roadblocks to effective communication, and the lack of a personal relationship between the person giving and the person receiving the feedback. Assistant and associate deans advised administrators to provide informal feedback through consistent, timely, and positive comments.

Several of the assistant and associate deans indicated that evaluations are reflections of people's perceptions. In other words, if you want to change evaluation outcomes, work toward changing people's perceptions.

Some common interview themes from the deans and assistant/associate deans included the following: utilizing feedback from multiple sources; establishing and tracking goal achievement; providing formal and informal feedback in a timely manner; being as objective, honest, and candid as possible; and recognizing that evaluations are time-consuming and thus the necessary commitment and effort must be devoted to the process. 


\section{Discussion}

It must be noted that the results of this study need to be interpreted with caution for at least two reasons. First, there are issues related to the sample. For example, it would have been possible that all of the assistant/associate deans from a given college participated in the study, but that the dean of that college did not or that a given dean participated and that none of the assistant/associate deans did. Additionally, two given deans could, respectively, have four and six assistant/associate deans, and all could have participated. If the first dean solicits performance feedback from students and the second dean does not, the results from these two sources would show that 50 percent of the deans solicit student feedback. However, if the assistant/associate deans all answered in accord with their deans, results for assistant/associate deans would show that deans solicit student feedback 40 percent of the time- a 10 percent difference between groups that likely is unimportant and even potentially misleading. Second, associate/assistant deans may lack awareness of some of the specific details related to the evaluation of their performance. For instance, a dean might solicit and combine feedback from sources about which assistant/associate deans are uninformed.

With the critical caveats immediately above acknowledged, Tables 1-5 indicate that some perceptual differences exist between deans and assistant associate deans regarding the sources of performance feedback, purposes of appraisal, and features of appraisals. It is fairly common for differences of viewpoint to develop across organizational levels, referred to as "semantic information distance." 23 The assistant/associate deans felt that the most important role of the appraisal process was assessment of job performance of their administrative roles. Deans, however, ranked personal development as the most important purpose of appraisals. In order to maximize the effectiveness of appraisals, the purposes need to be well defined and understood among the parties involved. Deans and assistant/associate deans rated differently the value of appraisals to assistant/associate deans' overall development, further underscoring the need to clarify the purpose of performance evaluations.

Assistant/associate deans also rated their satisfaction with the overall evaluation process (formal and informal) significantly lower than did the deans (3.65 vs. 4.05 ; ANOVA p=.02). Several reasons may account for this. First, most of the recommended features of formal appraisals are being utilized about 62 percent or less of the time (Table 3). Second, additional sources for feedback could be utilized more fully in appraisals. The concept of 360 degree performance appraisal is not being widely implemented at the time of this study. Third, as noted previously, there is a need to clarify the purpose(s) of appraisals. For example, assistant/associate deans ranked compliance with university policy/procedure as a purpose of appraisals more highly than did deans (3.58 vs. 4.17 ; ANOVA $p=.02$ ).

As was the case in the study comparing deans and department chairs, ${ }^{1}$ deans and assistant/associate deans differed significantly in their perceptions as to whether informal feedback is provided. Interestingly, however, views of the frequency of informal feedback were remarkably close. In addition, both groups responded in this study that informal feedback is provided "really only when necessary (a concern or something praiseworthy)" 33 percent and 42 percent of the time. While informal feedback received fairly high ratings of 4.14 and 3.95 from each on a fivepoint scale, there probably exists an opportunity to augment informal feedback.

Wagner and Harter argue persuasively that much of the anxiety in performance reviews can be successfully managed and the entire performance appraisal process greatly enhanced by providing consistent and timely informal feedback. ${ }^{24}$ They assert that "receiving regular, insightful, personal feedback - rather than a boilerplate review - is intensely powerful" (p. 1). Providing this type of feedback consistently may help resolve some of the differences of opinion regarding the purposes of formal appraisals. Further inquiry about the nature of informal feedback among administrators in dental colleges would likely yield important insights.

The existence of job descriptions seems to play an unexpectedly important role indicative of a dental college work environment with these characteristics: greater likelihood for being formally evaluated, receiving more informal feedback and giving deans performance feedback, and higher assistant/associate dean satisfaction with informal feedback. It would appear worthwhile to create and utilize job descriptions for assistant/associate deans.

The survey results showed that 45 percent of assistant/associate deans lack tenure. This fact may result in precarious implications for nontenured assistant/associate deans in terms of giving/receiving feedback and openness in the working relationship. 
Yet it must also be noted that nontenured individuals appear more likely to receive formal evaluations. This may be due to the need to provide documentation for academic advancement. Nontenured administrators likely serve at a dean's discretion. Further, they may have very specialized administrative responsibilities such as recruiting diverse faculty and students, fundraising, and securing grants. Additional inquiry needs to be made to examine the tenure process for individuals holding an administrative appointment. For example, does the administrator's tenure clock freeze during the period of the administrative appointment? If so, is the clock extended? If the untenured administrator does not have relief from the pressures of tenure, this may affect job performance in unexpected ways.

Survey results indicate that deans solicit some performance feedback from other sources when evaluating assistant/associate deans. Department chairs may be consulted up to 59 percent of the time and staff members as little as 14 percent of the time, with other constituents such as peers and students falling somewhere in between these extremes. However, interviewees identified a need for performance feedback from these multiple sources. So, perhaps it is not surprising that 53 percent of assistant/associate deans do not, in turn, provide performance feedback to deans. Still, some deans may be missing an opportunity to gain valuable feedback from constituents with whom assistant/associate deans work closely.

According to assistant/associate deans, deans with less experience in their role are more likely to formally evaluate assistant/associate deans and to do so more frequently. This tendency may reflect a necessary relationship-building step for establishing strategic direction and accountability within dental colleges and other organizations. Assistant/associate deans with more experience tend to receive less formal and informal feedback. Perhaps deans with longer-term assistant/associate deans tend to concentrate their feedback efforts on specific duties and direction or perhaps ponder how meaningful such feedback may be over time. Certainly, there exist a variety of working relationships, ranging from more to less formal and more to less effective. Informal feedback could be the most efficacious strategy given the right context (expectations and goals clear, openness in communication and frequent contact). Formal evaluations take time, effort, customization/flexibility, and commitment.

Differences in informal feedback were noted based on the type of college. Deans in nonpublic colleges rated satisfaction with informal performance feedback more highly than did their public dean peers. Further, assistant/associate deans in nonpublic colleges reported receiving informal feedback more than their public college peers. These findings may suggest that increased use of informal feedback is linked to higher levels of satisfaction with informal feedback. Admittedly only speculation, it may be that nonpublic colleges tend to encourage informal feedback as a more integral feature of their organizational milieu or ethos.

Overall, results of this study on assistant/associate deans tend to mirror the findings for appraising department chairs. ${ }^{1}$ Percentages, ratings, and rankings of similar survey questions are largely within close parameters. For example, in the two studies, 89 percent and 91 percent of deans reported formally evaluating assistant/associate deans and department chairs, respectively. Satisfaction ratings for the process and outcomes of performance appraisals all fell within a range of 3.8 to 4.1 . Both studies showed statistically significant differences in the perception about whether informal feedback was provided, with deans responding with 100 percent, assistant/associate deans with 83 percent, and chairs with 74 percent. Deans thus see themselves providing this feedback to both groups at levels higher than the recipients of the feedback

In light of the results highlighted in Tables 8 and 9 , it is noteworthy that assistant/associate deans appear more likely to have job descriptions than department chairs. Eighty-four percent of deans and 73 percent of assistant/associate deans responded that the later group had job descriptions. Seventy percent of deans and 50 percent of department chairs indicated that the latter group had job descriptions. Further, 55 percent of assistant/associate deans reported having tenure, compared to 73 percent of department chairs. Differences in responses based on job descriptions were not analyzed in the study of department chairs. No significant differences were noted in the study of department chairs based on tenure, although this study showed assistant/associate deans without tenure are more likely to be formally evaluated and more likely to receive informal feedback (see Table 9).

The study on department chairs and this study on assistant/associate deans both showed statistically significant differences in comparing each group with deans on the survey item related to the value of appraisals to the chair's personal development (3.92 vs. 3.32) and to assistant/associate dean's overall development (3.85 vs. 3.36$)$. The two items were 
admittedly phrased differently. Nevertheless, there seems to be a pattern of deans rating more highly the value of appraisals for development than those being evaluated. Deans and others probably would benefit from a discussion about how to make the evaluation process more effective in achieving development goals.

In reviewing the cumulative results of both studies, there may be a need to have a "paradigm shift" in terms being utilized to describe performance feedback. Performance management, ${ }^{25,26}$ coaching, growth conferences ${ }^{27}$ etc. probably capture the overall process more accurately and thoroughly than "performance appraisals" or "performance evaluations." Given that words tend to have behavioral implications, a change in terminology may enhance the performance feedback experience for all parties.

\section{Recommendations}

A number of recommendations were previously reported in the article examining the performance evaluations of department chairs. ${ }^{1}$ These included the following: yearly formal appraisals timed to coincide with the academic calendar; development/use of a standardized form with both open and close-ended questions; customized to some extent based on individual work priorities; timely, relatively private informal feedback on an ongoing basis throughout the year; strategic alignment of resources as a result of the appraisal process; a focus on individual growth and development of the individual; consideration to linking exemplary performance to rewards; incorporation of performance feedback from multiple sources (360 degree feedback); and exemplification of the standards of professionalism, honesty, and fairness.

As a result of this study, the following recommendations are added or reemphasized here as specifically applying to assistant/associate deans in dental colleges:

- Develop and utilize formal job descriptions tailored to specific assignments and priorities. Job descriptions appear related to formal evaluations and to informal feedback.

- Utilize performance feedback processes that specifically cover both performance assessment and personal development. These two purposes may need to be achieved with different methods.

- Conduct at least a yearly formal appraisal process for clearly stated purposes and based on expecta- tions documented in job descriptions and goals set for the next year.

- Provide ongoing informal feedback in order to augment and reinforce formal feedback in the interval between formal reviews or periodic updates on goal achievement.

- Utilize multiple sources of feedback, including self, and reflective of the various constituencies served by assistant/associate deans.

- Manage creatively the unique constraints related to career development for nontenured assistant/ associate deans.

- Maintain a performance appraisal system regardless of the length of service of the administrators conducting or receiving performance evaluations. Deans with reported terms of service of ten years or longer seemed to provide less performance feedback.

\section{Acknowledgments}

The authors thank Mr. Daryl Travnicek of the Department of Statistics, University of NebraskaLincoln, for providing data analysis services. The authors also thank the American Dental Education Association's Council of Sections Project Pool, the Section on Practice Administration, and the Section on Graduate and Postgraduate Education for funding this research. The Project Pool provides peer-reviewed funding of educational, research, and service activities that advance the mission of ADEA. Funding for this study came from the Project Pool and the two ADEA sections mentioned. The authors would also like to thank the reviewers for their helpful feedback in preparing this article.

\section{REFERENCES}

1. Dunning DG, Durham TM, Aksu MN, Lange BM. The state of the art in evaluating the performance of departmen chairs and division heads. J Dent Educ 2007;71(4):46779 .

2. Wolverton M, Gmelch WH, Montez J, Nies CT. The changing nature of the academic deanship. ASHE-ERIC Higher Education Research Report. New York: JosseyBass, 2001.

3. Romberg E. Dimensions of faculty evaluation of chair behaviors. J Dent Educ 1985;49(8):584-8.

4. McDowell EE. Administrators' perceptions of the performance appraisal interview. Minneapolis: University of Minnesota, 1999

5. Keith CL, Weiss SA, Leo AL. The role of the department chairman in faculty evaluation. J Dent Educ 1977;41(6):324-8. 
6. McDowell EE. Administrators' and faculty members' perceptions of the performance appraisal interview. Paper presented at the $72^{\text {nd }}$ Annual Meeting of the Speech Communication Association, Chicago, IL, November 1986.

7. Jones RF, Froom JD. Faculty and administration views of problems in faculty evaluation. Acad Med 1994;69(6):476-83.

8. Garson A Jr, Strifert KE, Beck JR, Schulmeier GA, Patrick JW, Buffone GJ, Feigin RD. The metric process: Baylor's development of a "Report Card" for faculty and departments. Acad Med 1999;74:861-70.

9. Howell LP, Hogarth MA, Anders TF. Implementing a mission-based reporting system at an academic health center: a method for mission enhancement. Acad Med 2003;78(6):645-51.

10. Reiser SJ. Linking excellence in teaching to departments' budgets. Acad Med 1995;70(4):272-5.

11. Hammons J, Thomas W. Performance appraisal of community college department/division chairpersons. Comm College Rev 1980;7(3):41-9.

12. Biebuyck JF, Mallon WT. The successful medical school department chair: a guide to good institutional practice. Module I: search, selection, appointment, transition. Washington, DC: Association of American Medical Colleges, 2002.

13. Biebuyck JF, Mallon WT. The successful medical school department chair: a guide to good institutional practice. Module II: characteristics, responsibilities, expectations, skill sets. Washington, DC: Association of American Medical Colleges, 2002.

14. Biebuyck JF, Mallon WT. The successful medical school department chair: a guide to good institutional practice. Module III: performance, evaluation, rewards, mentorship. Washington, DC: Association of American Medical Colleges, 2002.
15. Fenker RM. The evaluation of university faculty and administrators. J Higher Educ 1975;46(6):665-86.

16. Romberg E, Hovland EJ, Singer J, Myslinski NR. The development and implementation of a system to evaluate dental school administrators. J Dent Educ 1982;46(10):581-5.

17. Jones JE, Preusz GC. Evaluating dental faculty performance: perceptions of dental school deans. Psychol Rep 1989;64:647-51.

18. Boozer CH, Lee MM, Rayson JH. Faculty evaluation: a survey of dental school administrators. J Am Coll Dent 1981;48(2):102-7.

19. DiBiaggio J. The role of the dean in the evaluation process. J Dent Educ 1977;41(6):320-3.

20. Dittmar SS, Stuart CT, Elder RG. Evaluation of the school of nursing dean. J Nurs Educ 1990;29(6):283-5.

21. Finnerman MR. Trends in the evaluation of nursing deans. Nurs Outlook 1983;31(3):72-5.

22. American Dental Education Association. Directory of ADEA institutional members and association officers, 2005-06. Washington, DC: American Dental Education Association, 2005.

23. Tompkins P. Organizational communication: a state-ofthe-art review. In: Richetto $\mathrm{G}$, ed. Conference on organizational communication. Huntsville, AL: MSFC/NASA, 1968:4-26.

24. Wagner R, Harter JK. Performance reviews without the anxiety. Gallup Management Journal, July 13, 2007:1-7. At: http://gmj.gallup.com. Accessed: July 13, 2007.

25. Schwartz AE. Performance management. Hauppange, NY: Barron's Educational Series, 1999.

26. Armstrong M. Performance management: key strategies and practical guidelines. London: Kogan Page, Ltd., 2000 .

27. Morgan A. Nipping performance shortfalls in the bud! Dent Econ 2007;97(4). 